\title{
" L'Auteur
}

\section{DU \\ GRAND COUTUMIER \\ DE FRANCE}

\author{
PAR \\ Victor \\ LÉOPOLD DELISLE
}

P A R IS

1882 